OPEN ACCESS

Edited by:

Emilio Bastidas-Arteaga, Université de Nantes, France

Reviewed by: Marija Kuster Maric University of Zagreb, Croatia Antonio Formisano, University of Naples Federico II, Italy

*Correspondence: Johann F. Osma jf.osma43@uniandes.edu.co

Specialty section: This article was submitted to Bridge Engineering a section of the journal Frontiers in Built Environment

Received: 19 May 2020 Accepted: 03 November 2020 Published: 04 December 2020

Citation:

Segura CC and Osma JF (2020) Portable Measurement Systems Based on Microcontrollers to Test Durability of Structures: Mini-Review. Front. Built Environ. 6:563857. doi: 10.3389/fbuil.2020.563857

\section{Portable Measurement Systems Based on Microcontrollers to Test Durability of Structures: Mini-Review}

\author{
Crhistian C. Segura and Johann F. Osma* \\ Department of Electrical and Electronic Engineering, Universidad de los Andes, Bogota, Colombia
}

Corrosion presence is a recurrent concern in buildings and structures that use steel as their core or as reinforcement, due to the change of steel's properties caused by this phenomena. Therefore, methods to detect and quantify corrosion had been developed; some are based on electrical and electrochemical measurements. On reinforced concrete structures, sometimes there are exposed steel bars which are visible, but on those, a visual inspection could determine corrosion presence. There exist different options to measure the steel bars' corrosion and its level. The more straight forward consists of cutting through the concrete until the bar is exposed and connecting a measurement device there. A disadvantage of this technique is that steel has to be exposed to the environment during the measurement; as an alternative, novel contact-less electrochemical techniques are getting more popular. Recent advances in low-cost and portable electrochemical devices and embedded sensors can change how the structures are tested. Moreover, there is a discussion about how those devices, if developed for other fields as biosensors, can assist in other areas. This mini-review also gives some hints of what the future trends could be due to the combination of those areas.

Keywords: portable device, cyclic voltammetry (CV), steel corrosion, electrochemical impedance spectroscopy (EIS), corrosion

\section{INTRODUCTION}

From long ago, humans had been building bridges to connect cities, countries, and overcome obstacles; the materials used in these constructions have changed over the times, from the stone and wood to the modern bridges made of steel and concrete. These structures require periodical maintenance to keep them well, but a common cause of problems in bridges is corrosion in the steel bars due to the environment. In particular, the changes in temperature can cause small dilatations and contractions; also, the rainfalls could raise the humidity. These factors increase the probability that corrosion appears on the steel bars used during the construction. However, some researchers had developed models to predict corrosion (Tuutti, 1982; Guo et al., 2019) that are used to estimate the aging of a structure and the corrosion in advance. A fast approach to these models is using a Finite Element Method (FEM) and simulating Reinforced Concrete behavior due to corrosion as in Bossio et al. (2015). This corrosion could affect the durability of the steel and also reduce its ability to sustain strain, reducing the stress threshold as modeled in Deng et al. (2018). 
For example, the ultimate flexural capacity of reinforced concrete elements is decreased due to the corrosion of steel, as pointed out by Bossio et al. (2019b), they compared a set of experimental data against a non-linear FEM model. Netherless, the seismic capacity is directly affected by the corrosion level (Bossio et al., 2019a) shows how the mechanical properties such as ductility of the structure are affected, leading to structural failure during an earthquake. However, some researchers (Bossio et al., 2018) are working in a High-Performance Concrete (HPC) that could aid the structure to sustain stress and improve the structure ductility even in advanced corrosion levels. However, reasearchers (Formisano et al., 2018, 2019) discussed the use of non-destructive tests such as the leed hardness test to measure steel properties. These tests use a penetration device, which punctures a sample with a fixed force and measure the dent on the steel. Which using conversion tables can achieve the estimation of the material hardness. Otherwise Di Lorenzo et al. (2019) and Rizzo et al. (2019), present corrosion wastage models; which could be used to predict corrosion in steel. The model proposed by Rizzo et al. (2019) can estimate the corrosion depth in structures made of wrought iron. Meanwhile, the model of Di Lorenzo et al. (2019) based on experimental data obtained a model calibrated with measurements on both mild carbon and weathering steels.

There exist experimental measurements of corrosion propagation that use steel plates and a corrosion chamber that simulate environmental conditions (Odrobinák and Gocál, 2018). Such conditions are set to induce accelerated corrosion to model the behavior of steel of similar specifications on bridges. Authors of Alexander and Beushausen (2019) present a review of different ways to determine durability or service life prediction of RC structures. However, it critiques some of the current approaches and proposes the use of worldwide specifications and models that improve those parameters. Some common ions speed up the corrosion in the RC structures. One of the most studied is the Chloride ion, the penetration in the concrete (Wang et al., 2018), how it interacts with cracked concrete (Kušter Marić et al., 2020), and how it is transported to the steel. These studies lead to models that can characterize how the transport changes depending on the wetting/drying cycles (van der Zanden et al., 2015; Kušter Marić et al., 2020). In this mini-review, standard corrosion detection methods are presented, including commercial devices used; the third section shows recent developments in terms of low-cost and portable devices that meet similar criteria, also embedded sensors, and a benchmark. Finally, the last section presents a vision of future trends that gives hints about what problems these devices could solve.

\section{TYPICAL TECHNIQUES OF MEASUREMENT}

For bridges made of reinforced concrete, it is necessary to estimate the corrosion rate of steel embedded inside the concrete; for this, several techniques had been developed throughout the years. Usually, a routinary inspection consists of a visual test looking for rust or cracks in the structure, which could not give an accurate measurement of corrosion and its level inside the structure. On Marić et al. (2019), authors present some study cases of bridges and how the use of non-destructive techniques in routinary inspections can lead to more accuracy in find steel corrosion and their level inside structures. The most used technique is the Half-cell potential (HCP) (Poursaee, 2016), which is used to detect corrosion resistance of steel bars using a single contact point in the bar (electrode), and a second electrode on the concrete surface (Kawaai et al., 2019). Another common technique is linear-polarization-resistance (LPT). This technique involves applying a small voltage (usually about $30 \mathrm{mV}$ ) above and below its corrosion potential to the steel bar meanwhile the current is measured; with this, the polarization resistance (Rp) could be estimated, which is defined as the slope of the current-potential curve. Also, making use of the Tafel plot obtained, the corrosion rate could be estimated (Alexander and Orazem, 2020a). This technique requires a direct connection to the steel, which in some cases, implies digging across the concrete to expose the steel. To avoid this situation, researchers had explored the use of electrochemical analysis (Keddam et al., 2009; Alexander and Orazem, 2020b), with contact-less measurements, which could calculate steel corrosion using Electrochemical Impedance Spectroscopy (EIS). Those tests are made with lab potentiostats such as Gamry Reference 3000 (Gamry, USA) or VersaSTAT 4.0 (Princeton Applied Research).

The LPT analysis of reinforced concrete by EIS is used to obtain the polarization resistance ( $\mathrm{Rp}$ ) of the bar; this is on the EIS Nyquist charts. The typical impedance values could vary from $100 \Omega$ to $10 \mathrm{k} \Omega$; this difference could vary by electrodes distance and position, as described by Alexander and Orazem (2020a), where the Rp measured in the same reinforced concrete sample changed by 10 times due to the position of the electrodes on the surface. However, the corrosion measurement by impedance techniques could also test the effectiveness of anti-corrosive coatings, testing coated and uncoated samples (Alvarez-Pampliega et al., 2014; Raj et al., 2020) to test anti-corrosive coats properties. Those tests and measurements require an advanced electrochemical device such as the Autolab PGSTAT302 and algorithms developed to extract the information from the data like MATLAB.

\section{ELECTRONIC TECHNIQUES AND PORTABLE DEVICES}

There are currently attempts to reduce the size of electronic measurement devices, while keeping their characteristics and operation ranges. A field with a significant amount of these devices is the biosensors, in which they research low-cost and portable potentiostats suited for electrochemical tests. Some of those devices can carry out most of the standard electrochemical tests. For example, Segura and Osma (2017) developed a miniaturized potentiostat that can do Cyclic Voltammetry (CV). With applied voltages from -1.65 to $1.65 \mathrm{~V}$, measured currents from $80 \mu \mathrm{A}$ to $10 \mathrm{~mA}$, and impedances in the range of $50 \Omega$ to 20 $\mathrm{k} \Omega$. Other devices, like a low-cost amperometric device, can do 

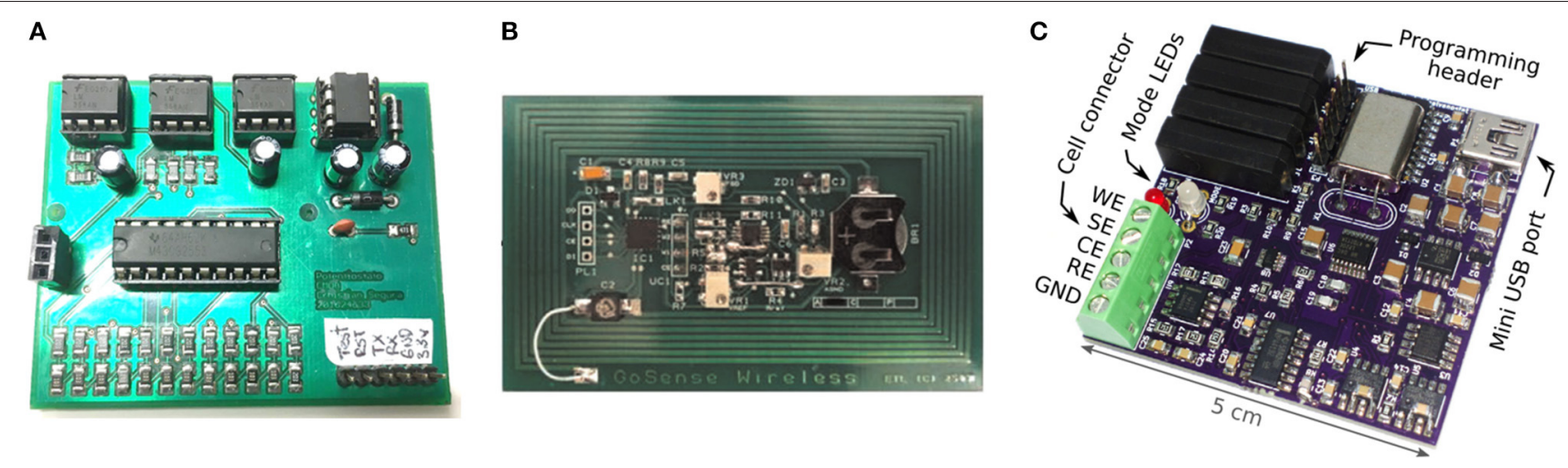

FIGURE 1 | Some of the portable devices for electrochemical measurements. (A) Miniaturized Potentiostat (Segura and Osma, 2017). (B) Wireless potentiostat (Steinberg et al., 2015). (C) USB Potentiostat Galvanostat (Dobbelaere, 2017).

TABLE 1 | Comparison of commercial and low-cost devices.

\begin{tabular}{|c|c|c|c|c|c|c|c|}
\hline & $\begin{array}{l}\text { Voltage } \\
\text { supply }\end{array}$ & $\begin{array}{l}\text { Techniques } \\
\text { supported }\end{array}$ & Operation Voltage & Communication & Size $\mathbf{W} \times \mathbf{H}$ & $\begin{array}{l}\text { Price one device } \\
\text { USD }\end{array}$ & $\begin{array}{l}\text { Current } \\
\text { measurement } \\
\text { capabilities }\end{array}$ \\
\hline $\begin{array}{l}\text { Miniaturized } \\
\text { Potentiostat (Segura } \\
\text { and Osma, 2017) }\end{array}$ & $3.3 \mathrm{~V}$ & CV & $-1.650 \mathrm{~V}$ to $1.650 \mathrm{~V}$ & USB & $4.45 \mathrm{~cm} \times 5.34 \mathrm{~cm}$ & N/A & $10 \mu \mathrm{A}$ to $10 \mathrm{~mA}$ \\
\hline $\begin{array}{l}\text { Wireless potentiostat } \\
\text { (Steinberg et al., 2015) }\end{array}$ & $3.3 \mathrm{~V}$ & CA & $-0.325 \mathrm{~V}$ to $0.900 \mathrm{~V}$ & NFC & $8.00 \mathrm{~cm} \times 5.00 \mathrm{~cm}$ & N/A & $15 \mathrm{nA}$ to $100 \mu \mathrm{A}$ \\
\hline $\begin{array}{l}\text { USB Potentiostat } \\
\text { Galvanostat } \\
\text { (Dobbelaere, 2017) }\end{array}$ & $5 \mathrm{~V}$ & CV & $-8.00 \mathrm{~V}$ to $+8.00 \mathrm{~V}$ & USB & $5.00 \mathrm{~cm} \times 5.00 \mathrm{~cm}$ & Below $\$ 100$ & $2.5 \mu \mathrm{A}$ to $25 \mathrm{~mA}$ \\
\hline $\begin{array}{l}\text { USB based sensor } \\
\text { (Bukkawar et al., 2019) }\end{array}$ & $5 \mathrm{~V}$ & LSV & $0.000 \mathrm{~V}$ to $3.300 \mathrm{~V}$ & USB & $19.81 \mathrm{~cm} \times 12.19 \mathrm{~cm}$ & $\sim \$ 47$ & $150 \mathrm{nA}$ to $250 \mu \mathrm{A}$ \\
\hline Autolab PGSTAT101 & $120 \mathrm{~V}$ & $\begin{array}{l}\text { SV, LSV, CV, ASV, } \\
\text { SWASV, CA }\end{array}$ & $-10.00 \mathrm{~V}$ to $10.00 \mathrm{~V}$ & USB & $9.00 \mathrm{~cm} \times 21.00 \mathrm{~cm}$ & More than $\$ 2.000$ & $10 \mathrm{nA}$ to $100 \mathrm{~mA}$ \\
\hline $\begin{array}{l}\text { PalmSens3 } \\
\text { Potentiostat/ } \\
\text { Galvanostat/ } \\
\text { Impedance Analyzer }\end{array}$ & $5 \mathrm{~V}$ & $\begin{array}{l}\text { SV, LSV, CV, ASV, } \\
\text { SWASV, CA, FRA/EIS: } \\
10 \mu \mathrm{Hz} \text { up to } 1 \mathrm{MHz}\end{array}$ & $-5.00 \mathrm{~V}$ to $5.00 \mathrm{~V}$ & $\begin{array}{l}\text { Wireless Bluetooth or } \\
\text { USB }\end{array}$ & $15.70 \mathrm{~cm} \times 9.70 \mathrm{~cm}$ & More than $\$ 2.000$ & $100 \mathrm{pA}$ to $10 \mathrm{~mA}$ \\
\hline
\end{tabular}

CVs with a voltage range from $0 \mathrm{~V}$ to $5 \mathrm{~V}$, and current measures up to $4.5 \mu \mathrm{A}$, with USB and Bluetooth connectivity (Agustini et al., 2020). Some of them had EIS measurement capabilities with a portable setup (Pruna et al., 2018; Barreiros dos Santos et al., 2019; Jenkins et al., 2019), with voltage and current ranges that could be used to measure corrosion. There are even opensource projects which share all the information required to build one of those portable devices. For example, Dobbelaere (2017) presents a potentiostat/galvanostat, design, and fabrication. Also Steinberg et al. (2015) developed an open-source potentiostat ABE-Stat with the EIS technique; this technique could be used on corrosion detection, as illustrated by Eid et al. (2020), Etim et al. (2020), and Kenny and Katz (2020). Figure 1, presents some of the portable devices mentioned in this section, those devices are portable and their cost is a fraction of commercial laboratory equipment.

However, other elements, such as embedded sensors, could improve a portable device corrosion measurement. For example, chloride-induced corrosion is a significant threat to reinforced concrete (Sandra et al., 2020); this is common in places near saltwater (Honglei et al., 2020). This effect had been studied for a long time, leading to experimental data and simulations (Chen et al., 2020). However, there exist researchers who are working on the detection of the presence of chloride ions. For example, Torres-Luque et al. (2017) developed a chlorideion detector made to be placed inside the reinforced concrete during the building process. This sensor detects and measures the concentration of chloride-ions, using capacitors made of Calcium Aluminate. Due to the geometrical disposition of the capacitors, it had the potential to measure the corrosion direction. Furthermore, its low cost and small size make it possible to be placed throughout the entirety of the bridge or structure. Table 1 presents a comparison between commercial devices and some of the portable devices mentioned in this section.

\section{DISCUSSION}

Corrosion and electrochemical tests, in general, require complicated and expensive devices and specialized laboratories. 
Nevertheless, due to recent advances in technology, some researchers had developed their own low-cost and portable devices, which gives technological independence. Additionally, those custom made devices had small dimensions, making them portable and a perfect choice for fieldwork. The portability also refers to the supply voltage independence, which is usually of $5 \mathrm{~V}$. This voltage could be easily provided by batteries or any USB port from a laptop. Some of them even could be powered remotely by NFC technology, which makes them perfect for embedding inside the concrete, and carrying out measurements in place, reporting data wirelessly to a smartphone or a laptop. This option could yield to obtain and process the data in situ, which gives an advantage over the commonly used processes.

Therefore, some commercial brands have also started developing their own portable devices, but they still are expensive. However, they have excellent specifications, and this takes advantage of the know-how and the infrastructure that backs them up. Nevertheless, there exists a gap when there are large structures such as bridges or buildings, for which it may be beneficial to have more readouts and even to had embedded sensors and devices that allow continuous monitoring of the corrosion. In the future, those low-cost devices could be embedded in a large structure, and using IoT technologies and lots of sensors, can create a mesh that could get a

\section{REFERENCES}

Agustini, D., Fedalto, L., Agustini, D., de Matos dos Santos, L. G., Banks, E. C., Bergamini, M. F., et al. (2020). A low cost, versatile and chromatographic device for microfluidic amperometric analyses. Sens. Actuat. B Chem. 304:127117. doi: 10.1016/j.snb.2019.127117

Alexander, C. L., and Orazem, M. E. (2020a). Indirect impedance for corrosion detection of external post-tensioned tendons: 2. multiple steel strands. Corros. Sci. 164:108330. doi: 10.1016/j.corsci.2019.108330

Alexander, C. L., and Orazem, M. E. (2020b). Indirect electrochemical impedance spectroscopy for corrosion detection in external post-tensioned tendons: 1. proof of concept. Corros. Sci. 164:108331. doi: 10.1016/j.corsci.2019. 108331

Alexander, M., and Beushausen, H. (2019). Durability, service life prediction, and modelling for reinforced concrete structures - review and critique. Cem. Concr. Res. 122, 17-29. doi: 10.1016/j.cemconres.2019.04.018

Alvarez-Pampliega, A., Hauffman, T., Petrova, M., Breugelmans, T., Muselle, T., van de Bergh, K., et al. (2014). Corrosion study on Al-rich metal-coated steel by odd random phase multisine electrochemical impedance spectroscopy. Electrochim. Acta 124, 165-175. doi: 10.1016/j.electacta.2013.09.159

Barreiros dos Santos, M., Queirós, R. B., Geraldes, Á., Marques, C., VilasBoas, V., Dieguez, L., et al. (2019). Portable sensing system based on electrochemical impedance spectroscopy for the simultaneous quantification of free and total microcystin-LR in freshwaters. Biosens. Bioelectron. 142:111550. doi: 10.1016/j.bios.2019.111550

Bossio, A., Fabbrocino, F., Monetta, T., Lignola, G., Prota, A., Manfredi, G., et al. (2019a). Corrosion effects on seismic capacity of reinforced concrete structures. Corros. Rev. 37, 45-56. doi: 10.1515/corrrev-2018-0044

Bossio, A., Imperatore, S., and Kioumarsi, M. (2019b). Ultimate flexural capacity of reinforced concrete elements damaged by corrosion. Buildings 9:160. doi: 10.3390/buildings 9070160

Bossio, A., Lignola, G. P., and Prota, A. (2018). An overview of assessment and retrofit of corroded reinforced concrete structures. Procedia Struct. Integr. 11, 394-401. doi: 10.1016/j.prostr.2018.11.051 fast measurement of the status of the structure and how the environment affects it over time.

\section{AUTHOR CONTRIBUTIONS}

Both authors made substantial contributions to the present review in equal shares.

\section{FUNDING}

This research was funded by the Colombian Ministry of Education and the Administrative Department of Science, Technology, and Innovation, Colciencias, through the program for national doctorates, grant 727 .

\section{ACKNOWLEDGMENTS}

The authors acknowledge the support of the Los Andes University and 727 Colciencias doctoral scholarships for their support during the development of this system. Also, We thank the Cleanroom laboratory and the Printed Circuit Board Facility of the Electrical and Electronic Engineering Department at Universidad de los Andes for access to the instruments and technical support.
Bossio, A., Monetta, T., Bellucci, F., Lignola, G. P., and Prota, A. (2015). Modeling of concrete cracking due to corrosion process of reinforcement bars. Cem. Concr. Res. 71, 78-92. doi: 10.1016/j.cemconres.2015.01.010

Bukkawar, S., Sarwade, N., and Panse, M. (2019). Polyaniline assisted USB based sensor for determination of benzene biomarker. Sens. Bio Sens. Res. 22:100260. doi: 10.1016/j.sbsr.2019.100260

Chen, J., Zhang, W., Tang, Z., and Huang, Q. (2020). Experimental and numerical investigation of chloride-induced reinforcement corrosion and mortar cover cracking. Cem. Concr. Compos. 111:103620. doi: 10.1016/j.cemconcomp.2020.103620

Deng, P., Zhang, C., Pei, S., and Jin, Z. (2018). Modeling the impact of corrosion on seismic performance of multi-span simply-supported bridges. Constr. Build. Mater. 185, 193-205. doi: 10.1016/j.conbuildmat.2018.07.015

Di Lorenzo, G., Rizzo, F., Formisano, A., Landolfo, R., and Guastaferro, A. (2019). Corrosion wastage models for steel structures: literature review and a new interpretative formulation for wrought iron alloys. Key Eng. Mater. 813, 209-214. doi: 10.4028/www.scientific.net/KEM.813.209

Dobbelaere, T. (2017). A USB-controlled potentiostat/galvanostat for thin-film battery characterization. HardwareX 2, 34-49. doi: 10.1016/j.ohx.2017.08.001

Eid, J., Takenouti, H., Ait Saadi, B., and Taibi, S. (2020). Electrochemical studies of steel rebar corrosion in clay: Application to a raw earth concrete. Corros. Sci. 168:108556. doi: 10.1016/j.corsci.2020.108556

Etim, I. I. N., Dong, J., Wei, J., Nan, C., Pokharel, D. B., Umoh, A. J., et al. (2020). Effect of organic silicon quaternary ammonium salts on mitigating corrosion of reinforced steel induced by SRB in mild alkaline simulated concrete pore solution. J. Mater. Sci. Technol. doi: 10.1016/j.jmst.2019.10.006

Formisano, A., Chiumiento, G., and Di Lorenzo, G. (2018). Leeb hardness experimental tests on carpentry steels: Surface treatment effect and empirical correlation with strength. AIP Conf. Proc. 1978:450004. doi: 10.1063/1.5044058

Formisano, A., Dessì, E. J., and Chiumiento, G. (2019). Non-destructive tests on carpentry steels. Open Constr. Build. Tech. J. 13(Suppl. 2), 214-249. doi: $10.2174 / 1874836801913010214$

Guo, Z., Ma, Y., Wang, L., and Zhang, J. (2019). Modelling guidelines for corrosion-fatigue life prediction of concrete bridges: Considering 
corrosion pit as a notch or crack. Eng. Fail. Anal. 105, 883-895. doi: 10.1016/j.engfailanal.2019.07.046

Honglei, C., Zuquan, J., Tiejun, Z., Benzhen, W., Zhe, L., and Jian, L. (2020). Capillary suction induced water absorption and chloride transport in nonsaturated concrete: the influence of humidity, mineral admixtures and sulfate ions. Constr. Build. Mater. 236:117581. doi: 10.1016/j.conbuildmat.2019.117581

Jenkins, D. M., Lee, B. E., Jun, S., Reyes-De-Corcuera, J., and McLamore, E. S. (2019). ABE-Stat, a fully open-source and versatile wireless potentiostat project including electrochemical impedance spectroscopy. J. Electrochem. Soc. 166, B3056-B3065. doi: 10.1149/2.0061909jes

Kawaai, K., Nishida, T., Saito, A., Ujike, I., and Fujioka, S. (2019). Corrosion resistance of steel bars in mortar mixtures mixed with organic matter, microbial or other. Cem. Concr. Res. 124:105822. doi: 10.1016/j.cemconres.2019.105822

Keddam, M., Nóvoa, X. R., and Vivier, V. (2009). The concept of floating electrode for contact-less electrochemical measurements: application to reinforcing steel-bar corrosion in concrete. Corros. Sci. 51, 1795-1801. doi: 10.1016/j.corsci.2009.05.006

Kenny, A., and Katz, A. (2020). Steel-concrete interface influence on chloride threshold for corrosion - empirical reinforcement to theory. Constr. Build. Mater. 244:118376. doi: 10.1016/j.conbuildmat.2020.118376

Kušter Marić, M., Ožbolt, J., Balabanić G., Zhychkovska, O., and Gambarelli, S. (2020). Chloride transport in cracked concrete subjected to wetting - drying cycles: numerical simulations and measurements on bridges exposed to deicing salts. Front. Built Environ. 6:561897. doi: 10.3389/fbuil.2020.561897

Marić, M. K., Vlašić, A., Ivanković, A. M., Bleiziffer, J., Srbić, M., and Skokandić, D. (2019). Assessment of reinforcement corrosion and concrete damage on bridges using non-destructive testing. Gradjevinar 71, 843-862. doi: 10.14256/JCE.2724.2019

Odrobinák, J., and Gocál, J. (2018). Experimental measurement of structural steel corrosion. Procedia Struct. Integr. 13, 1947-1954. doi: 10.1016/j.prostr.2018.12.266

Poursaee, A. (2016). Corrosion measurement and evaluation techniques of steel in concrete structures. Corr. Steel Concrete Struct. 2016, 169-191. doi: 10.1016/B978-1-78242-381-2.00009-2

Pruna, R., Palacio, F., Baraket, A., Zine, N., Streklas, A., Bausells, J., et al. (2018). A low-cost and miniaturized potentiostat for sensing of biomolecular species such as TNF- $\alpha$ by electrochemical impedance spectroscopy. Biosens. Bioelectron. 100, 533-540. doi: 10.1016/j.bios.2017.09.049

Raj, R., Morozov, Y., Calado, L.M., Taryba, M. G., Kahraman, R., Shakoor, R. A., et al. (2020). Calcium carbonate particles loaded with triethanolamineand polyethylenimine for enhanced corrosion protection of epoxy coated steel. Corros. Sci. 167:108548. doi: 10.1016/j.corsci.2020.108548

Rizzo, F., Di Lorenzo, G., Formisano, A., and Landolfo, R. (2019). Time-dependent corrosion wastage model for wrought iron structures. J. Mater. Civ. Eng. 31:04019165. doi: 10.1061/(ASCE)MT.1943-5533.0002710

Sandra, N., Kawaai, K., and Ujike, I. (2020). Influence of copper slag on corrosion behavior of horizontal steel bars in reinforced concrete column specimen due to Chloride-induced corrosion. Constr. Build. Mater. 255:119265. doi: 10.1016/j.conbuildmat.2020.119265

Segura, C. C., and Osma, J. F. (2017). Miniaturization of cyclic voltammetry electronic systems for remote biosensing. Int. J. Biosens. Bioelectron. 3, 297-299. doi: 10.15406/ijbsbe.2017.03.00068

Steinberg, M. D., Kassal, P., Kereković, I., and Steinberg, I. M. (2015). A wireless potentiostat for mobile chemical sensing and biosensing. Talanta 143, 178-183. doi: 10.1016/j.talanta.2015.05.028

Torres-Luque, M., Osma, J. F., Sánchez-Silva, M., Bastidas-Arteaga, E., and Schoefs, F. (2017). Chlordetect: commercial calcium aluminate based conductimetric sensor for chloride presence detection. Sensors 17:2099. doi: 10.3390/s17092099

Tuutti, K. (1982). Corrosion of Steel in Concrete. Stockholm: Swedish Cement and Concrete Research Institute.

van der Zanden, A. J. J., Taher, A., and Arends, T. (2015). Modelling of water and chloride transport in concrete during yearly wetting/drying cycles. Constr. Build. Mater. 81, 120-129. doi: 10.1016/j.conbuildmat.2015. 02.012

Wang, X. H., Bastidas-Arteaga, E., and Gao, Y. (2018). Probabilistic analysis of chloride penetration in reinforced concrete subjected to pre-exposure static and fatigue loading and wetting-drying cycles. Eng. Fail. Anal. 84, 205-219. doi: $10.1016 /$ j.engfailanal.2017.11.008

Conflict of Interest: The authors declare that the research was conducted in the absence of any commercial or financial relationships that could be construed as a potential conflict of interest.

Copyright (๑) 2020 Segura and Osma. This is an open-access article distributed under the terms of the Creative Commons Attribution License (CC BY). The use, distribution or reproduction in other forums is permitted, provided the original author(s) and the copyright owner(s) are credited and that the original publication in this journal is cited, in accordance with accepted academic practice. No use, distribution or reproduction is permitted which does not comply with these terms. 